\title{
A munkáltatással összefüggésben elkövetett emberkereskedelem jellemzői elméleti és gyakorlati szempontból
}

\author{
Theoretical and Practical Characteristics \\ of Human Trafficking for Labour Purpose
}

\section{Windt Szandra}

Dr. PhD, tudományos fömunkatárs, Országos Kriminológiai Intézet windt@okri.hu

\begin{abstract}
Absztrakt
Az emberkereskedelem jelenségével foglalkozó tanulmányok és az azok alapját szolgáló kutatások fókuszában jellemzően a szexuális kizsákmányolás áll. Sajnálatos tény, hogy hazánkban a munkacélú, munkáltatással összefüggő kizsákmányolásra kevés figyelem hárul, nem beszélve az úgynevezett egyéb célúról (mint a szervkereskedelem vagy a kényszerházasság). Az alábbi tanulmány rövid elméleti bevezetőt, majd a statisztikai adatok ismertetését követően igyekszik a munkáltatással összefüggésben elkövetett büncselekményeket tipizálni, egy ügy összetettségét szemléltetni.

Cél: Az elméleti és gyakorlati ismeretek, tapasztalat szintézise, egy eset rendőrszakmai szempontú elemzésén keresztül a nehézségek, lehetőségek, a proaktivitás bemutatására kerül sor.

Módszertan: A statisztikai adatok elemzése, nemzetközi szakirodalom feldolgozása és egy ügy részletes ismertetése képezi tanulmányunk alapját.

Megállapítások: A közösség szerepe rendkívül fontos a munkacélú kizsákmányolás elleni küzdelem során: felismerjék a jelenség jellemzőit, és ha azokat észlelik, arról a rendőrséget értesítsék. A sikeres felderítéshez néhány dolog rendkívül fontos: a lakosság körében a tudatosságnövelés, a segítségnyújtás módjainak ismertté tétele. Emellett a rendőri szervek közötti információáramlást, a rendelkezésre álló információk megfelelő elemzését, értékelését szükséges kiemelni ahhoz, hogy ezekben sikeres legyen a nyomozás.
\end{abstract}


Érték: A munkacélú kizsákmányolás elméleti és gyakorlati szempontú megközelítése, amely a proaktivitás erősítésében, az ügyek sikeresebb felderítésében, nyomozásában segítség lehet.

Kulcsszavak: munkacélú emberkereskedelem, kényszermunka, Magyarország, áldozat, proaktivitás

\section{Abstract}

Studies and underlying research on the phenomenon of trafficking in human beings focus on sexual exploitation. It is an unfortunate fact that in our country (Hungary) little attention is paid to labour exploitation, let alone to other purposes (such as organ trafficking or forced marriage). The following study, after a brief theoretical introduction and statistical data, aims to typify employment-related crime.

Aim: To synthesise theoretical and practical knowledge and experience, to present the difficulties, opportunities.

Methodology: This study based on analysis of statistical data, review of international literature and detailed presentation of a case.

Findings: The role of the community is crucial in the fight against labour exploitation: to recognise the characteristics of the phenomenon and, if detected, to report them to the police. A few things are crucial for successful detection: raising awareness among the public, making them aware of ways to help. In addition, the flow of information among different police forces, proper analysis, and evaluation of the information available must be emphasised to successfully investigate these cases.

Value: a theoretical and practical approach to labour exploitation, which can help to increase proactivity to improve the success of detecting and investigating these cases.

Keywords: trafficking in human beings for labour, Hungary, victim, proactivity

\section{Bevezetés}

Az emberkereskedelem összetett jelenség, sokszor határon átnyúló, amelyben szinte mindig több elkövető vesz részt (Ricard-Guay \& Hanley, 2020). Az adásvétel aktusától némileg eltávolodva ma már sokkal inkább a kizsákmányolás, a hosszú távú haszon- és előnyszerzés a központi elem. Összességében a Varsói Egyezmény alapján: emberkereskedelem a személyek kizsákmányolás céljából 
való toborzása, szállítása, átadása, rejtegetése vagy fogadása fenyegetéssel, erőszakkal vagy egyéb kényszer alkalmazásával, emberrablással, csalással, megtévesztéssel, hatalommal vagy a kiszolgáltatott helyzettel való visszaélés révén, illetve anyagi ellenszolgáltatásnak vagy előnyöknek valamely személy felett ellenőrzést gyakorló személy beleegyezésének megszerzése érdekében történő nyújtásával vagy elfogadásával. A kizsákmányolás lehet szexuális célú [a prostitúció révén történő kizsákmányolás vagy a szexuális kizsákmányolás más formái (URL6), szexuális kényszerítés (Btk. 196. §), gyermekpornográfia (Btk. 204. §)], munkacélú [ezzel kapcsolatban különböző kifejezések léteznek: kényszermunka, munkaerő-kizsákmányolás céljából folytatott emberkereskedelem (Plant, 2015)], és úgynevezett egyéb célú (a büncselekményre kényszerítést, a kényszerházasságot, a szervkereskedelemet említi a nemzetközi szakirodalom). A munkacélú kizsákmányolással kapcsolatos definíciók sokszínűsége nemzetközi szinten sem szerencsés: a szolgaság, rabszolgaság, kényszermunka, munkacélú kizsákmányolás mind igyekszik e jelenség egyes jellemzőit lefedni, mégis azok különböző jelentéstartalma nehézségeket okoz a nemzetközi összehasonlítás során. Erre jó példa az Emberi Jogok Európai Bírósága (EJEB) határozatainak indokolása, többek között a 2017. március 30-án született Chowdhury és mások vs. Görögország ügyében hozott határozat (URL1; URL7), de említhettük volna az összes ügyet, amely az Emberi Jogok Európai Egyezménye 4. cikke (a rabszolgaság és a kényszermunka tilalmáról) alapján indult (Council of Europe, 2021). Ezekben az EJEB igyekszik felvázolni a különbséget a szolgaság, a rabszolgaság, a kényszermunka és a munkacélú emberkereskedelem között (URL7).

A magyar tényállás neve alapján szerencsésebb mégis inkább kényszermunkának nevezni a munkáltatással összefüggésben elkövetett emberkereskedelmet, annak ellenére is, hogy Irk Ferenc szerint annak történelmi okok miatt ellenségelvü és büntetéscentrikus jelentése is van (Irk, 2020). Ez vitathatatlan, ahogy az is, hogy ezen kifejezések hétköznapi használata, például a modern rabszolgaság, a csicskáztatás a jelenség sokszínüségére, megfoghatatlanságára is rámutat. Mi az alábbiakban a kényszermunka és a házi szolgaság kifejezésekkel igyekszünk a tanulmány témájául választott cselekményeket meghatározni.

\section{A kényszermunka (Btk. 193. §) jellemzői a statisztikai adatok alapján}

A statisztikai adatok elemzése, ahogy sok más büncselekmény esetében is, a kényszermunkával kapcsolatban is rendkívül kevés információt tartalmaz (az emberkereskedelemmel kapcsolatos bünügyi adatok elemzése nemcsak 
nálunk nehézkes) (Albrecht, 2019). Az emberkereskedelemhez képest a kényszermunka még kevésbé volt látható a Btk.-ba bekerülése óta, 2013. július elsejét követően. Rendkívül magas a látencia, 2013 és 2020 között csupán egy évben volt tíznél több regisztrált kényszermunka ügy, holott egyes vélemények szerint hazánkban a „házi szolgák” száma ennél lényegesen magasabb (például a Global Slavery Index 2018-as adatai alapján Magyarországon harminchatezer „rabszolga” élt) (URL2).

Egy tényfeltáró riport részletesen is beszámolt arról, hogy „,százötven embert tartanak modernkori rabszolgaságban, csicskaként Szarvason. Az egész város tud róla, mindenki név szerint ismeri a csicskákat" (URL3).

A 2013. július elseje és 2020. június 30-a között hatályban lévő Btk. 193. §-a alapján büntetendő kényszermunka tényállás az Egységes Nyomozóhatósági és Ügyészségi Bűnügyi Statisztika (ENyÜBS) adatai alapján a hazánkban megvalósított büncselekmények mindegyike befejezett volt, azt jellemzően itthon és magyar sértett sérelmére valósították meg. Tanulmányunk szempontjából fontos megemlítenünk, hogy a regisztrált kényszermunka ügyekben (a statisztika alapján) leginkább a sértetti feljelentés után kezdődött el a büntetőeljárás. A kényszermunka büntett hazai megjelenésének egyik jellemzője, hogy ezeket föleg a lakóhelyen valósították meg.

A kényszermunka esetén az erőszak, a kiszolgáltatott helyzet kihasználása és a fenyegetés voltak a legjellemzőbb módszerek.

A hivatalos adatok alapján a kényszermunka ügyekben az elkövető és a sértett közötti kapcsolat alapján elmondható, hogy ismerősök voltak, az uzsorás, a szomszéd az, aki elkövetöje ennek a cselekménynek.

A rendelkezésünkre álló ismeretek szerint a kényszermunka büntettét felnőtt magyar férfi valósítja meg, aki jellemzően büntetlen előéletü (Windt, 2020).

2021 októberében, e tanulmány írásakor, az elérhető ENyÜBS adatok alapján némi változás mutatkozik: a kényszermunka (Btk. 193. §) miatt indult ügyek száma a sokéves átlaghoz képest magasnak mondható, annak ellenére is, hogy 2020. július elseje óta ez a tényállás nem létezik önállóan, de 2021-ben regisztrálták ezeket az eljárásokat a statisztikában. Emellett 2020. július elsejét követően a statisztika az emberkereskedelem és kényszermunka (Btk. 192. §) tényállás alapján munkacélú kizsákmányolás büncselekményt is mutat. A jelenlegi adatokból trendeket, messzemenő következtetéseket még nem lehet levonni. Annyi bizonyos csupán, hogy ezen ügyek száma növekszik, amely hosszú távon segít majd megismerni a jelenséget, és közelebb visz minket ahhoz, hogy nagyságrendileg meghatározzuk, hogy hány áldozat lehet. 


\section{A kényszermunkával kapcsolatos nyomozások tapasztalatai}

Az emberkereskedelem és kényszermunka 2020. július elsejétől egy tényállásban került szabályozásra, lényegében egyszerübbé vált a munkáltatással összefüggésben megvalósított, valamint a munka jellegü kizsákmányoló, büntetendő magatartások minösítése. Az elkövetési magatartások a gyakorlatban könnyebben értelmezhetők, alkalmazhatók, valamint a minősítési rendszer is átláthatóbbá vált a kényszermunka vonatkozásában a nyomozó hatóságok tapasztalatai szerint.

A statisztikai adatok és a rendőrök gyakorlati ismeretei sokszor távol állnak egymástól, de ez kevéssé magyar sajátosság (Cockbain, Boxers \& Vernon, 2020). A kényszermunka ügyekben a nyomozó hatóságok beszámolói alapján általánosságban megállapítható, hogy kevés olyan esetben indult nyomozás, ahol a sértett maga tett feljelentést. A büncselekmények többsége más személy bejelentése, névtelen bejelentés, vagy más büncselekmény elkövetésének gyanúja miatt folytatott eljárásban, az eljáró hatóság észlelése alapján vált ismertté.

A munkáltatással összefüggésben elkövetett emberkereskedelem nyomozási tapasztalatai szerint a sértettek valamennyien valamiféle „megállapodás” alapján váltak áldozattá. Az elkövetők a legtöbb esetben az „önkéntességre, saját akaratra" építve, a nehéz élethelyzetben lévő áldozat ,jó szándékú” támogatása okán nyújtott segítségre hivatkozva vették rá őket a beleegyezésre. A beleegyezés kérdéskörének vizsgálata során azonban gyorsan kiderült, hogy az ajánlatok minden esetben egy, az élethelyzetéhez, körülményeihez, lehetőségeihez képest pozitív, minőségi változást, előrelépést kínáltak az áldozatnak. Ilyenek voltak a lakhatás, élelmezés folyamatos biztosítása, a jövedelem, az idősebb, magányos áldozatoknál a családi élet, ellátás, gondoskodás ígérete. A „beleegyezést” követően a segítségnyújtással ellentétes, fokozatosan erősödő kizsákmányoló, bántalmazó magatartást csak jóval később ismerték fel az áldozatok, vagy fel sem ismerték (ez a nemzetközi tapasztalatok alapján is így van) (van Meeteren \& Hiah, 2020). Nem ritka az az eset sem, hogy a sértett attól való félelme miatt, hogy a korábbi, kilátástalannak tünő léthez kell visszatérnie, maradni szeretne a kizsákmányolt helyzetben, mert úgy értékeli, hogy az jobb, mint a korábbi helyzete. (Ez sem egyedi, magyar sajátosság, lásd az ír jellemzőket Doyle, Murphy, C., Murphy, M., s Coppari \& Wechsler, 2019.)

A sértettek jelentős része hosszú ideje életvezetési problémákkal, betegségekkel, függőségekkel küzd, hajléktalan, akik, ha fel is ismerték kiszolgáltatott helyzetüket, azt megváltoztathatatlannak gondolták, abba beletörődtek. A büntetőeljárás megindulását követően mindaddig, amíg bizonyosságot nem szereztek arról, hogy van lehetőségük jelenlegi helyzetükből kilépni, vonakodtak vallomást tenni, vagy csak részben tárták fel a történteket. 
A tapasztalatok szerint a biztonságos környezet (védett házak), az áldozatsegítő szervezetek támogatása jelentősen elősegíti az áldozat részvételét a büntetőeljárásban.

\section{A kiszolgáltatott helyzet}

„A kiszolgáltatott helyzet olyan helyzet, amelyben az adott személy tényleges vagy elfogadható választási lehetöség hiányában kénytelen alávetni magát az adott visszaélésnek." (Az irányelv különösen kiszolgáltatott helyzetben lévő személynek tekinti fóként a gyermekeket, ugyanakkor hangsúlyozza, hogy az áldozat kiszolgáltatottságának vizsgálatakor más tényezőket is figyelembe lehet venni, például az áldozat nemét, egészségi állapotát, fogyatékosságát, illetve azt, hogy várandós-e.) Ennek megállapításához szükséges adatok összegyüjtése a nyomozó hatóságok feladata, minden esetben a konkrét bünügyben a sértett helyzetének, korábbi életkörülményeinek feltárásával lehet leginkább eljutni.

A Legfőbb Ügyészség e témakörben készült iránymutatásaiban foglaltak (KSB. 3771/18/5-I.-NF. 3889/2014/11., és a KSB. 3771/2018/45-II.-NF. 3889/2014/17II) alapján a nyomozó hatóságoknak nem okoz jelentős problémát a körülmények tisztázása, mindemellett széles körü bizonyítást igényel. A sértett korábbi körülményeinek, helyzetének, választási lehetőségének hiányáról nem csak az áldozat vallomása alapján kaphatunk képet, azonban tény, hogy bizonyos kérdésekben csak ő adhatja meg a választ. Néhány büntetőeljárásban erre a sértett nem volt képes, mely több okra volt visszavezethetö (fogyatékosság, szégyen, előző életkörülmények rejtése, azok a minimális előnyök, melyeket kizsákmányolása idején megkapott, érzelmi függőség, az általa elkövetett büncselekmények leplezése). Ezekben az esetekben nem tudta/akarta elmondani a vele történteket, vagy nem közölt minden információt, vagy csak később közölt további részleteket a vele történtekröl.

A körülmények lehető legpontosabb feltárása érdekében vallomása mellett további eljárási cselekmények (szakértők bevonása, helyszíni szemle, előző életkörülmények, vagyoni helyzet, további tanúk felkutatása, kihallgatása, bevonása az eljárásba) végrehajtása indokolt. A kiszolgáltatott helyzetre vonatkozó adatok beszerzése minden esetben szükséges, azokban az ügyekben is, ahol az áldozat önmagát nem érzi áldozati helyzetben, nincs tisztában azzal, hogy

1 Az Európai Parlament és a Tanács 2011/36/EU irányelve (2011. április 5.) az emberkereskedelem megelőzéséről, és az ellene folytatott küzdelemről, az áldozatok védelméről, valamint a 2002/629/IB tanácsi kerethatározat felváltásáról, 2. cikk (2) bekezdés. 
bűncselekmény áldozatává vált. Általános megállapítás az ilyen jellegü ügyekben a nyomozó hatóságok részéről, hogy a sértettek többségében nem tudatosul (büncselekmény) áldozati mivoltuk mindaddig, amíg komolyabb bántalmazás, kínzás, sanyargatás nem éri őket, vagy a velük azonos helyen tartózkodó áldozatokat. A nyomozások egy részében akkor sem mertek segítséget kérni, az őket sanyargató személyek ellen fellépni, ha számukra is nyilvánvaló volt kizsákmányolásuk.

A kiszolgáltatott helyzet megítélését azonban nehezítheti az eljárásban, hogy a sértettek az elkövetővel vagy az elkövetők valamelyikével valamilyen jellegü ,függőségi” viszonyba kerültek az eltelt idő alatt.

Több ügyben számoltak be arról is, hogy nem először zsákmányolták ki őket, korábban is voltak ilyen élethelyzetben, amely azt mutatja, hogy bár sikerült kikerülniük korábbi kizsákmányolóik felügyelete alól, újra áldozattá váltak (Héra, Bakó \& Hárs, 2021).

A megoldást azokban az esetekben, amikor az áldozat azonosítása megtörténik, kizárólag az azonnali kiemelése az addigi környezetéből, biztonságba helyezése jelentheti, így mindamellett, hogy haladéktalanul segítséget kap, megakadályozható az újbóli áldozattá válás, valamint az elkövetők további befolyása, amely a büntetőeljárás sikeres lefolytatását jelentősen megnehezítheti, vagy akár ellehetetlenítheti.

\section{Az elkövetők}

A büncselekmény elkövetői nagyon rövid időn belül, olykor még a kizsákmányoló tevékenységüket megelőzően alakítanak ki az áldozatokkal egyfajta aláfölé rendeltségi viszonyt, gyorsan a hatalmuk, befolyásuk alá vonják őket. Ezek közül a leggyakrabban tapasztalt módszerek:

- meglévő függőségek (alkohol, drog, dohányzás) kihasználása, fenntartása, elősegítése, néhány esetben a függőség kialakítása;

- személyes kapcsolatok fenntartásának, kialakításának irányítása, befolyásolása;

- okmányok, mobiltelefon valótlan indokokkal történő elvétele, elzárása;

- szabad mozgás akadályozása, korlátozása, folyamatos felügyelete;

- valótlan ígéretek a jövőt illetően, folyamatos tévedésben tartás;

- szabad akarat megtörése fenyegetéssel, fizikai bántalmazással, sanyargatással.

A kényszermunka büncselekményt tartalmazó ügyeket az elkövetés módszere, helye és jellege alapján négy nagyobb csoportba lehetett sorolni (Windt, 2020). 
Elenyésző esetben, de előfordultak a büntetés-végrehajtási intézetekben és kollégiumokban zajló „klasszikus” csicskáztatásos ügyek, amikor az egyik bent lakó a másik félelmét kihasználva a saját feladatainak ellátására kötelezi a sértett felett. Emellett a hazai kényszermunka egyik jellemzője a ház körüli munka (mással történő) elvégeztetése. A munkacélú kizsákmányolások esetében jellemzö, hogy magukhoz költöztetik áldozataikat, így is biztosítva az áldozat kiszolgáltatott helyzetének fenntartását, amelyet folyamatosan erósítenek is.

Emellett előfordult az is, amikor az elkövető albérlőként költözött a sértetthez - eleinte segítőként -, a sértett ingatlanába, ahol lassan megszerezte az uralmat a sértett fölött. Ez kevésbé hosszú ideig tartó elkövetés volt.

Ezekben az ügyekben a sértettek sokkal inkább mertek a rendőrséghez fordulni segítségért.

Az azonos lakóhely fenntartása egyrészt a környezet számára láthatatlanná teszi a kiszolgáltatottság, kizsákmányolás mibenlétét, másrészt tanúk és bizonyítékok nélkül nehezebben vonható kétségbe az elkövetők ,jó szándékú segíteni akarása" a nehéz helyzetben lévő, hajléktalan, fogyatékos, ellátás nélküli, magányos stb. áldozat részére. Különösen azokban az esetekben nehéz az elkövetők védekezését megcáfolni, amikor az áldozat állapota miatt nem képes felidézni a vele történteket, vagy az elkövetővel és annak rokonaival már kialakult egy „függőségi viszony”, amely miatt szinte családjának tekinti kizsákmányolóit, és nem érzi magát áldozatnak. Nem ismerik fel a helyzetüket, vagyis azt, hogy számukra ez milyen hátrányokat okozott. A nyomozások tapasztalatai alapján előfordult, hogy egy-egy áldozat még akkor sem ismerte fel kiszolgáltatott helyzetét, amikor kizsákmányolóik vagyonuk, ingatlanuk eladására, tulajdonjog átruházására, ajándékozására vették rá őket, vagy esetleges rendszeres jövedelmüket (nyugdíj, szociális juttatás) vették el tőlük folyamatosan. Amennyiben a háztartási, házkörüli teendők elvégzése mellett egyéb munkát is el kell végeznie az áldozatnak (idényjellegü mezőgazdasági munkák, építőipari segédmunkák, állatgondozás), akkor a munkáltatóval a kapcsolatot kizsákmányolóik tartották, bérüket ők kapták kézhez, abból az áldozatnak nem vagy csak minimális összeget adtak át.

Az emberkereskedelem és kényszermunka vagyont generáló büncselekmény, így a büncselekményböl származó jövedelmek és a büncselekményekhez kapcsolódó egyéb javak felkutatására, azonosítására és a vagyonbiztosítás érdekében teendő feladatokról szóló 20/2018. (V. 31.) ORFK utasítás értelmében kötelezően vizsgálni kell a büncselekményből származó vagyon elvonásának a lehetöségét.

Ez különösen azokban az ügyekben merült fel, ahol a hajléktalan szállók mellett a kórházakban történő toborzást követően a cél a kényszerkoldultatás volt, 
amelynek során a kiszolgáltatott helyzetü, sok esetben végtaghiányos, rossz egészségi állapotban lévő sértett napi 10-12 órát volt kénytelen - időjárástól függetlenül - az utcán tölteni. (Ezzel kapcsolatban említendő a Heves Megyei Főügyészség 719/2014 számú ügye. A Heves Megyei Föügyészség a Legfőbb Ügyészségi iránymutatását követően felülvizsgálati indítványt nyújtott be a Kúria részére, amelyet 2019. október 24-én tárgyaltak. A Bfv. II. 600/2019/13 számú Kúriai végzés a jogerős másodfokú ítéletet hatályon kívül helyezte, és az Egri Törvényszéket új elsőfokú eljárásra utasította. Ebből született egy BH is: BH 2020.2.30 Emberkereskedelem - és nem kényszermunka - büntette valósul meg, ha a munkavégzésre kényszerítés kiszolgáltatott személy sérelmére, e helyzetének a kihasználásával, előny szerzése érdekében történik, és az elkövető kizsákmányolás céljából sértetteket toboroz, szállít és elszállásol. Btk. 192. §, 193. §.)

A nyomozó hatóságok tapasztalatai szerint azonban problémát jelent az emberkereskedelem és kényszermunka törvényi tényállásában meghatározott „rendszeres előnynek" a Btk. 74. § (1) és (2) bekezdésében meghatározott vagyonelkobzással érintett vagyonnak való megfeleltetése, a szerinti meghatározása. Ez különösen az olyan munkajellegü kizsákmányolásoknál igaz, ahol a „rendszeres előny" kézzel foghatóan nem határozható meg, például amikor az elkövetési magatartás kizárólag az elkövető, valamint családtagjai szükségleteinek kielégítésére irányuló munkavégzésre való kényszerítésben, rábírásban jelenik meg. A vagyoni hátrány, illetve a szerzett vagyoni előny meghatározása különösen nehéz akkor, amikor a sértett tevékenysége például az úgynevezett házi munkákra korlátozódik (háztáji ellátása naponta, takarítás, kerti és udvari munka stb.). Emellett ide sorolhatók azok az esetek is, amikor a sértett valamilyen jogcímen kapott szociális járandóságát az elkövetők helyette felveszik, egy bizonyos részét az áldozatra költik, vagy teljes egészében saját megélhetésükre fordítják (például élelmiszer, alkohol, dohánytermék vásárlása).

A nemzetközi szakirodalom szerint az elkövetök a kevéssé szabályozott területeket próbálják kihasználni, leginkább a szezonálisakat: mezőgazdaság, takarítás, építkezés, halászat stb. Ahol külföldit „alkalmaznak”, sok esetben legális foglalkoztatás és a munkacélú kizsákmányolás közötti szürke zónát igyekeznek megteremteni: sokan az eredeti országuk minimálbérét kapják csak, de a tapasztalatok alapján ez hazánkban kevéssé jellemző. Magyar sértett sérelmére viszont Hollandiában követtek el munkacélú emberkereskedelmet, amely miatt ott büntetőeljárás is indult. A férfi sértett napi 35 eurót keresett autómosással Eindhovenben, a munkaidő 9-20 óráig tartott, a szállásért 250 eurót vontak le a fizetéséből, bántalmazták, megfenyegették. Egy magyar nő végezte itthon a toborzást, hirdette a jól fizető állást, de az elkövetők nem magyarok voltak. 
A gyanúsítottak munkavállalóikat kizsákmányolták, kizárólag külföldieket foglalkoztattak, akik holland nyelvtudás hiányában nem tudták milyen jogokkal rendelkeznek (Windt, 2020).

Hazánkban a klasszikus harmadik országbeliek munkacélú kizsákmányolásával kapcsolatos eset alig volt, ezzel összefüggésben a nemzetközi jelentések mindig megfogalmazzák aggodalmukat. Hangsúlyozandó, hogy a férfi áldozatok, különösen a külföldiek, a számukra járó áldozatsegítő szolgáltatásokat ritkán kívánják igénybe venni.

Egy pakisztáni nő esete a sajtóból vált ismertté:

„2019-ben Budapestre érkezett két férfit munkaadójuk a csepeli háza pincéjében szállásolta el. A pakisztáni nö elvette szakácsai iratait, napi 14-18 órát dolgoztatta öket, a megbeszélt bérnek pedig csak töredékét fizette. A szakácsokat a nö többi között azzal félemlitette meg, hogy ha a hatóságokhoz fordulnak, lopással vádolja meg és börtönbe juttatja öket, illetve vissza fogja vonatni a vizumukat, és kitoloncolásuk után tönkreteszi Pakisztánban élö családjaik életét is. A XXI. kerületi rendörök egy másik eljárással kapcsolatban szereztek tudomást a szakácsok életkörülményeiröl, és nyomozást inditottak az étteremtulajdonos ellen. A nyomozók 2020. június 16-án gyanúsitották meg a pakisztáni nöt." (URL4).

Ezt követően 2021-ben az Országos Idegenrendészeti Főigazgatóságon egy 37 éves, építőipari munkásként dolgozó mongol férfit sikerült emberkereskedelem áldozataként azonosítani, azonban a részére felajánlott áldozatsegítési szolgáltatásokkal nem kívánt élni.

„Engedélyügyi eljárásban, a munkavállalási célú tartózkodási engedély hoszszabbitása kapcsán került azonositásra az OIF Budapesti és Pest megyei Regionális Igazgatóságának ügyfélszolgálatán. A munkáltatója biztositás és járulékok fizetésére hivatkozva visszatartotta a fizetését, elvették a tartózkodási engedélyét és csak 200 ezer forint fejében lettek volna hajlandók visszaadni. "2

A jogi képviselő ezt követően, 2021. július 20-án e-mail útján ugyanazon munkáltató alkalmazásában állt további három fő mongol állampolgár sérelmére elkövetett cselekményről értesítette a fóigazgatóságot. Ezekben az ügyekben tudomásunk szerint a büntetőeljárásokat megszüntették.

2 Az áldozat azonosításról készült, EKAT-ban rögzített adatlap adataiból. 


\section{Egy eset bemutatása és annak tanulságai}

Az alábbiakban a bünügyi iratban és a vádiratban található adatok alapján egy anonimizált esetet mutatunk be részletesebben.

A tanulmány írásakor a vádiratot már benyújtották, azonban az elkövetők bünösségét a bíróság még nem állapította meg.

Egy városi rendőrkapitányság nyomozói kábítószer birtoklása miatt indított eljárásban, házkutatás végrehajtása céljából egy kistelepülésen kerestek fel egy ingatlant. A kényszerintézkedéssel érintett és kábítószer-fogyasztással gyanúsítható férfi lakóhelyén kábítószert nem találtak, ugyanakkor több személy nevére kiállított személyes okmányok, tulajdonjog átruházásról szóló iratok, illetve gépjármü adás-vételi szerződések is elő kerültek.

Az ingatlan mellett lévő $8 \mathrm{~m}^{2}$ alapterületű nyári konyhában egy férfi lakott, aki a rendőröknek elmondta, hogyan került oda, és miként él ott a férfivel és annak élettársával.

Az elmondottak és a helyszínen tapasztaltak alapján az intézkedő rendőrök megállapították, hogy a nyári konyhában élő idős férfi feltehetően emberkereskedelem áldozata. Az eljárást ennek megfelelően folytatták tovább, és értesítették az eljárás lefolytatására hatáskörrel rendelkező illetékes főkapitányságot.

A 66 éves férfi kihallgatásakor elmondta, hogy otthona leégett, és a helyzetével, körülményeivel (munka, jövedelem, család nélkül) tisztában lévő, őt korábbról jól ismerő elkövető felajánlotta neki, hogy lakjon nála. A lakhatásért dolgoznia kell, de a munka jellegérôl nem tájékoztatta. A szóbeli megállapodás szerint jó körülmények között, egy nyári konyhában élhet, a munkáért kapott keresményét megtarthatja. Megígérte a sértettnek azt is, hogy bejelenti őt az ingatlanba állandó lakosnak, legyen lakcíme, de később kiderült, az ingatlan csak bérlemény volt.

Az áldozat 2018 júliusában költözött az ingatlan nyári konyhájába, ahol egészen a rendőrök 2020. februári kiérkezéséig élt. A helyiséget beköltözése előtt ki kellett takarítania, abban egy heverő, egy hokedli és egy szekrény volt. Tisztálkodási lehetőség és WC nem volt, ezen szükségleteit az udvaron kellett elvégeznie.

Odaköltözését követően a hétvégéken a ház körüli teendőket és annak felújításával kapcsolatos építőipari munkálatokat kellett elvégeznie (kertrendezés, kaszálás, gépkocsi mosás, gépkocsi felhajtó betonozása), amiért pénzt nem kapott, hétközben pedig kizsákmányolója vitte különbözö építkezésekre dolgozni másokkal együtt. Az ígért napi 8000 forint munkabérből reggel 2000 forintot kapott, a fennmaradó 6000 forintot nem kapta meg. Az áldozat megtartott munkabéréből az elkövető a nyomozás adatai szerint legalább 2400000 forinttal gazdagodott. 
A napi nehéz fizikai munka után általában egy tál ételt kapott vacsorára, de többször előfordult, hogy még azt sem. Az idős férfi testsúlya a munkavégzés és a rendszertelen étkezés következtében 54 kilogrammról 47 kilogrammra csökkent. Az áldozatot kizsákmányolója soha nem szólította a nevén, mások előtt is rabszolgájának nevezte, gyakran kiabált vele, pofon ütötte, és amikor nem tudott aludni, a sértetettnek is ébren kellett vele eltöltenie az éjszaka egy részét.

Hétvégén többször azért kellett hajnalban felkelnie, hogy az elkövető és annak élettársa által használt lakóházban kitisztítsa a kályhát és begyújtson. A sértett által lakott nyári konyhában kályha nem volt, egy hősugárzót kapott melegítésre, amit az elkövető a tél folyamán időszakosan többször elvitt tőle, mivel túl sok áramot fogyasztott.

A sértett az ingatlan területéről elmehetett, de ehhez engedélyt kellett kérnie, és mindig meg kellett mondania, hogy hová megy. Egy alkalommal, mikor engedély nélkül hagyta el lakóhelyét, visszaérkezését követően kizsákmányolója szigetelőszalaggal kezeit hátra kötözte, nyakába láncot tett és a kerítéshez kikötözte. A sértett elmondása szerint további két alkalommal kötözte ki őt ilyen módon azért, mert közölte vele, hogy nem akar ott lakni és neki dolgozni.

Nem csak munkavégzésre kényszerítette, egy alkalommal a közeli városba mentek az elkövető barátjával hárman, ahol egy korábbról mindhármuk által ismert nőt vettek fel az autóba. A nő önként ment velük a sértett lakóhelyére, ahol a nyári konyhában a részeg barátját arra utasította a házigazda, hogy erőszakolja meg a nőt. A szexuális erőszakot követően a jelenlévő idős sértettet utasította arra, hogy közösüljön a nővel. Az elkövető mindkét esetről telefonjával felvételt készített.

A sértett többször töltötte idejét a közeli kocsmában, ahol panaszolta életkörülményeit a pultos nőnek, aki későbbi kihallgatása alkalmával elmondta, hogy a „kisöreg” alkalmanként beszélt neki az őt ért sérelmekröl. Továbbá több személyt említett, akik hozzá hasonló körülmények között, hosszabb-rövidebb ideig éltek az ingatlanban. A végrehajtott eljárási cselekmények (előzménykutatás, adatkérések, tanúkihallgatások) alapján további két áldozatot azonosítottak az eljárásban.

Az egyik áldozat elmondta, hogy hajléktalan szállón volt, amikor megjelent ott két, számára ismeretlen személy, akik egy „puccos helyen” munkát és ellátást ígértek neki. Az ajánlatot elfogadta, mire a két férfi autóba ültette és a 190 km távolságra lévő településre vitték, ahol egy férfi (azonos az idős sértett kizsákmányolójával) a két férfinak 70000 forintot fizetett érte. Két hétig tartózkodott ott, a nyári konyhában szállásolták el - a már ott lakó sértett mellé -, egy szekrényajtón aludt a földön, amin volt egy matrac. Élet- és ellátási körülményei azonosak voltak a másik áldozatéval. Dolgoznia egyszer kellett (vaskerítés 
szétszedése), ezen kívül a csikkeket kellett összeszednie az udvaron alkalmanként. Többször próbált onnan eljönni, de amint észrevették a szándékát az őt megvásárló férfi megfenyegette, hogy megveri és úgy is megtalálja őt bárhol. Egy alkalommal sikerült a háztól eljönnie, buszra szállt, de amint észrevették, hogy eltünt, megtalálták és visszavitték. A szökése után az elkövető azt mondta neki, addig nem mehet el tőle, amíg az érte kifizetett összeget le nem dolgozza. Nem sokkal ezt követően az áldozat ismét megszökött, a szomszédos településre gyalogolt, ahol a rendőrség értesítéséhez segítséget kért. A sértettel kapcsolatos előzménykutatás során az eljáró hatóság megállapította, hogy eltűnés miatt körözését rendelték el, valamint korábban, autóbalesetben elszenvedett egészségkárosodása (fejsérülés) következtében gondnokság alatt áll.

A harmadik áldozatot a közeli város hajléktalan szállóján kereste fel az elkövető, és építőipari segédmunkát ajánlott neki napi 9000 forintos munkabérrel. A 61 éves férfi többnapi munkáért mindössze 5000 forintot kapott. A hajléktalan szálló tatarozása miatt a sértettnek nem volt hová mennie, munkaadója felajánlotta neki, hogy költözzön hozzá, szállást és élelmezést kap, valamint napi 2000 forintot a munkavégzésért. Az ajánlat elfogadása után a sértettet az udvaron álló kisbuszban helyezte el kizsákmányolója, amelyben fütési lehetőség nem volt, élelmezési és tisztálkodási körülményei ugyanolyanok voltak, mint a többi áldozatnak, vacsorát alkalmanként nem kaptak, az udvaron tisztálkodhattak, anyagcsere szükségleteiket az udvar gazos területén vagy a közeli kocsma mellékhelyiségében végezhették el.

A napi munkavégzésen felül neki házkörüli teendőket is el kellett látnia, a munkabér az ígért 2000 forint helyett rövid időn belül csak 1000 forint volt.

Személyazonosító igazolványát, lakcím kártyáját, közgyógyellátási igazolványát (amit később az elkövető hálószobájában foglaltak le) feltehetően akkor vette el kizsákmányolója, amikor kabátját annak autójában felejtette. Okmányai eltünéséről a sértett azt gondolta, hogy valahol elveszítette.

A több szálon futó nyomozás során a kábítószer-birtoklás, szexuális erőszak, szexuális kényszerítés, okirattal visszaélés, közokirat hamisítás elkövetése megalapozott gyanújának alátámasztásához szükséges bizonyítékok összegyüjtése mellett az áldozatok által feltárt kizsákmányoló magatartás, az elkövető pénzügyi gyarapodása, a sértettek kiszolgáltatott helyzetének alátámasztásához szükséges bizonyítékok beszerzése komoly feladatot jelentett az eljáró nyomozó hatóságnak. Ennek érdekében alapos helyszíni szemlét, kutatást követően számtalan adatkérést hajtottak végre, 26 tanút hallgattak ki, a vagyonfelderítés érdekében adatkérésekkel ellenőrizték a gyanúsított és annak élettársa jövedelmi viszonyait (NAV, hitelintézetek, Központi Hitelinformációs Rendszert Működtető Zrt., Kormányhivatal Egészségbiztosítási Pénztári Szakigazgatási Szerv, Western 
Union, Intercash Zrt., Exclusive Cash Zrt., Magyar Posta Zrt. stb.). Mindemellett a büncselekmények elkövetésének bizonyításához indokolt volt a lefoglalt mobiltelefonok adatainak mentése, elemzése-értékelése, szakértők kirendelése (igazságügyi toxikológiai, pszichológiai, elmeszakértői, írászszakértői vélemények). Az újabb adatok ismeretében folyamatos elemző-értékelő munkát követően a sértettek többszöri kihallgatása elkerülhetetlen volt.

Tovább nehezítette a bizonyítást, hogy két sértett a vallomását visszavonta a nyomozás alatt, az egyik sértett ellentétes tartalmú vallomását közjegyző által hitelesített okiratba foglaltan, postai úton küldte meg a letartóztatásban lévő gyanúsított meghatalmazott védője. A sértett későbbi kihallgatása alkalmával elmondta, hogy a gyanúsítotthoz közeli személyek kérték meg, hogy vonja vissza vallomását, aminek ő eleget tett. Ezért pénzt nem kapott, nem fenyegették és nem kényszerítették. Az ügyvédhez és a közjegyzőhöz önként ment, az általa készített iratot elmondása szerint nem olvasta el, csak kérésre aláírta. Az okirat keletkezésének körülményeit, az érintettek büntetőjogi felelősségét külön eljárásban vizsgálják.

A másik sértett esetében egy távoli város egyik postáján adtak fel nyilatkozatot a vallomása visszavonásáról. Az eljáró hatóság a nyilatkozat feladása körülményeinek vizsgálata alapján (postai kamerafelvételek beszerzése, elemzése) megállapította, hogy azt nem a sértett adta fel. A felvételek alapján teljes bizonyossággal nem lehetet megállapítani a feladó személyazonosságát, de hasonlóságot az érdekeltek körében igen. Ennek alapján újabb eljárási cselekmények végrehajtását követően sikerült megállapítani a visszavonó nyilatkozat postára adójának személyazonosságát. Az eljárás folytatását nehezítette, hogy a sértett eltünt, így folytatólagos kihallgatására nem volt mód. Tartózkodási helyének megállapítását követően, ismételt kihallgatása alkalmával elmondta, hogy a hajléktalan szállón keresték meg őt az onnan majd 200 km-re élő személyek, akik egy előre elkészített visszavonó nyilatkozattal érkeztek. Az aláírásért 30000 forintot ajánlottak neki, melyet ő elfogadott. Az érintettek büntetőjogi felelösségét ebben az esetben is külön eljárásban vizsgálják.

A nyomozás a folyamatos munka ellenére másfél évig tartott, a gyanúsított letartóztatása és ügyészi felügyelet mellett. A gyanúsított végig tagadta bünösségét, a tanúkihallgatások alapján a lakókörnyezetben több személy tisztában volt a sértettek életkörülményeivel, de voltak olyanok is, akik a gyanúsított segítő szándékát, jóakaratát nem vonták kétségbe. Mindemellett több tárgyi eszközt is sikerült felkutatni a bizonyítás érdekében.

Az eljáró nyomozó hatóság két rendbeli a Büntető Törvénykönyvről szóló 2012. évi C. törvény 192. § (2) bekezdésébe ütközö és a (4) bekezdés c) pontja szerint minősülő emberkereskedelem büntett; 
- egy rendbeli, a Büntető Törvénykönyvről szóló 2012. évi C. törvény 192. $\S$ (2) bekezdésébe ütköző és a (3) bekezdés i) pontja szerint minősülő emberkereskedelem büntett;

- három rendbeli, a Büntető Törvénykönyvröl szóló 2012. évi. C. törvény 194. § (1) bekezdésébe ütköző és a (2) bekezdés c) pontja szerint minősülő a sértett sanyargatásával elkövetett személyi szabadság megsértése büntett;

- egy rendbeli, a Büntető Törvénykönyvről szóló 2012. évi C. törvény 197. $\S$ (1) bekezdés a) pontjába ütköző és a szerint minősülő erőszakkal, illetve az élet vagy testi épség elleni közvetlen fenyegetéssel elkövetett szexuális erőszak büntett - figyelemmel a Btk. 14.§ (1) bekezdésére - mint felbujtó;

- egy rendbeli, a Büntető Törvénykönyvről szóló 2012. évi C. törvény 196. § (1) bekezdésébe ütköző és a szerint minősülő szexuális kényszerítés büntett;

- hét rendbeli, a Büntető Törvénykönyvről szóló 2012. évi. C. törvény 342. $\S$ (1) bekezdés c) pontjába ütköző és a szerint minősülő közokirat-hamisítás büntett;

- három rendbeli, a Büntető Törvénykönyvről szóló 2012. évi. C. törvény 346. $\S$ (1) bekezdés c) pontjába ütköző és a szerint minősülő okirattal visszaélés büncselekmények elkövetésének megalapozott gyanúját közölte a gyanúsítottal. Az illetékes ügyészség valamennyi büncselekmény vonatkozásában vádiratot nyújtott be az illetékes bírósághoz.

\section{Befejezés}

A munkacélú kizsákmányolás, a munkáltatással kapcsolatban elkövetett emberkereskedelem elleni küzdelem nemcsak a magyar hatóságoknak okoz nehézséget. A jelenség komplexitása, az érdekelt felek megtalálása, az információszerzés és a bizonyítás más országokban is kihívások elég állítja a hatóságok tagjait. Erre jó példa a finn HEUNI szervezet 2018-2020 között zajló programja, amelyben a munkacélú kizsákmányolás pénzügyi modelljét igyekeztek feltárni a három balti állam és Bulgária gyakorlatán keresztül (Flows of illicit funds and victims of human trafficking: uncovering the complexities 2018-2020, (URL5).

A munkacélú kizsákmányolás hazai fő megjelenési formája az úgynevezett házi szolgaság, a ház körüli munkáltatás, sok esetben emellett bűncselekmények elkövetésére kényszerítés. A ház körüli munkáltatás, a lakóhelyen történő kizsákmányolás az egyébként is látenciában lévő cselekményeket még inkább a négy fal közé rekeszti. Ezekben az ügyekben rendkívül fontos a közösség szerepe. A részletesen bemutatott esetben is a környezet tudhatta, láthatta, hogy valaki él a nyári konyhában, sőt a pultos nőnek be is számolt a kocsma látogatásakor 
a sértett arról, hogy milyen körülmények között kénytelen létezni. Ha a pultos nő tudja és ismeri azokat a lehetőségeket, ahova bejelentést tehetett volna, a sértett talán korábban kiléphetett volna ebből a helyzetből. Az ismertetett nyomozás mindhárom sértettjét rögtön az első kihallgatásuk alkalmával tájékoztatta az eljáró nyomozó hatóság biztonságos elhelyezésük lehetőségéről. Ennek ellenére, csak egyikük kért segítséget az úgynevezett „védett házba” elhelyezéséhez, így ő volt az egyetlen, akit nem találtak meg, akit nem befolyásoltak az eljárás alatt, és aki ezáltal esélyt kapott arra, hogy biztonságos körülmények között, segítséggel folytathassa és talán megváltoztathassa addigi életét.

\section{Felhasznált irodalom}

Albrecht, H.-J. (2019). Measuring Human Trafficking. In Haverkamp, R., Herlin-Karnell, E. \& Lernestedt, C. (Eds.), What is wrong with Human Trafficking? (pp. 37-51). HART.

Cockbain, E., Boxers, K. \& Vernon, L. (2020). Using Law Enforcement Data in Trafficking Research. In Winterdyk, J. \& Jones, J. (Eds.), The Palgrave International Handbook of Human Trafficking, (pp. 1709-1732). Palgrave Macmillan. https://doi.org/10.1007/978-3-319-63058-8_100 Council of Europe (2021). Guide on Article 4 of the European Convention on Human Rights. https://www.echr.coe.int/Documents/Guide_Art_4_ENG.pdf

Doyle, D. M., Murphy, C., Murphy, M., s Coppari, P. R. \& Wechsler, R. J. (2019). 'I Felt Like She Owns Me': Exploitation and Uncertainty in the Lives of Labour Trafficking Victims in Ireland. The British Journal of Criminology, 59(1), 231-251. https://doi.org/10.1093/bjc/azy025 Héra G., Bakó Cs. \& Hárs M. (2021). Az emberkereskedelem férfi áldozatainak egyedi ellátási igényei. https://emberkereskedelem.kormany.hu/download/4/fc/d2000/Az\%20emberkereskedelem $\% 20 f \%$ C3\%A9rfi $\% 20 \%$ C3\%Alldozatainak $\% 20$ egyedi $\% 20$ ell $\%$ C3\%A1t $\%$ C3\%A1si\%20ig\%C3\%A9nyei.pdf

Irk F. (2020). A munkavégzők kizsákmányolása és az európai értékek védelme. In Madai S., Pallagi A. \& Polt P. (Szerk.), Sic itur ad astra, Ünnepi kötet a 70 éves Blaskó Béla tiszteletére (pp. 241-249). Ludovika Egyetemi Kiadó.

Plant, R. (2015). Forced Labour, Slavery and Human Trafficking: When do definitions matter? Anti-Trafficking Review, (5), 153-157, http:/gaatw.org/ATR/AntiTraffickingReview_issue5.pdf Ricard-Guay, A. \& Hanley, J. (2020). The Challenge of Addressing Both Forced Labour and Sexual Exploitation. In Winterdyk, J. \& Jones, J. (Eds.), The Palgrave International Handbook of Human Trafficking (pp. 287-302). Palgrave Macmillan. https://doi.org/10.1007/9783-319-63058-8_16

van Meeteren, M. \& Hiah, J. (2020). Self-Identification of Victimization of Labour trafficking. In Winterdyk, J. \& Jones, J. (Eds.), The Palgrave International Handbook of Human Trafficking (pp. 1605-1618). Palgrave Macmillan. https://doi.org/10.1007/978-3-319-63058-8_86 
Windt Sz. (2020). Az emberkereskedelem és a kényszermunka jellemzői egy empirikus vizsgálat alapján. In Vókó Gy. (Szerk.), Kriminológiai Tanulmányok 57 (pp. 192-215). Országos Kriminológiai Intézet.

\section{A cikkben szereplő online hivatkozások}

URL1: The European Court Of Human Rightscase Of Chowdury And Others V. Greece. https:// hudoc.echr.coe.int/eng\#\{\%22itemid\%22:[\%22001-172701\%22]\}

URL2: Modern Slavery: A Hidden, Every Day Problem. https://www.globalslaveryindex.org/

URL3: Szarvason mindenki név szerint ismeri a csicskákat. https://abcug.hu/szarvason-mindenki-nev-szerint-ismeri-a-csicskakat/

URL4: Pakisztáni nö dolgoztatott éhbérért pakisztánit egy budapesti étteremben. https://infostart.hu/bunugyek/2021/02/28/pakisztani-no-dolgoztatott-ehberert-pakisztanit-egy-budapesti-etteremben

URL5: FLOW. Flows of illicit funds and victims of human trafficking: uncovering the complexities. https://heuni.fi/-/flow

URL6: Emberkereskedelem elleni küzdelem Magyarországon. https://ec.europa.eu/anti-trafficking/eu-countries/hungary_en

URL7: Az emberkereskedelem és kényszermunka. https://jogaszvilag.hu/vilagjogasz/az-emberkereskedelem-es-kenyszermunka/

\section{Alkalmazott jogszabályok}

2012. évi C. törvény a Büntető Törvénykönyvről

2013. évi XVIII. törvény, az Európa Tanács Emberkereskedelem Elleni fellépésről szóló egyezményének kihirdetéséröl

Az Európai Parlament és a Tanács 2011/36/EU irányelve (2011. április 5.) az emberkereskedelem megelőzéséről, és az ellene folytatott küzdelemről, az áldozatok védelméről, valamint a 2002/629/IB tanácsi kerethatározat felváltásáról

\section{A cikk APA szabály szerinti hivatkozása}

Balogh K. \& Windt Sz. (2022). A munkáltatással összefüggésben elkövetett emberkereskedelem jellemzői elméleti és gyakorlati szempontból. Belügyi Szemle, 70(2), 259-275. https:// doi.org/10.38146/BSZ.2022.2.3 